\title{
Pre-plant soil fumigation for control of violet root rot of carrots
}

\author{
I.J. Horner, E.G. Hough and B.M. Fisher \\ The New Zealand Institute for Plant \& Food Research Limited, Hawke's Bay Research \\ Centre, Private Bag 1401, Havelock North, New Zealand \\ Corresponding author:ian.horner@plantandfood.co.nz
}

\begin{abstract}
Violet root rot (VRR), caused by Rhizoctonia crocorum, causes substantial economic losses and threatens the long-term viability of the carrot industry in the Ohakune region, New Zealand. Previous attempts at control have been largely unsuccessful. Preplanting soil fumigation trials were carried out in two heavily infested Ohakune carrot fields. In 2007/08, chloropicrin+dichloropropene (Tri-Form ${ }^{\oplus 6}$ ) and metam sodium (Fumasol $^{\mathrm{TM}}$ ) failed to provide a commercially useful level of VRR control. Deficiencies in fumigant placement and distribution, and inadequate sealing of the soil for gas retention were identified as likely reasons for the failure. Modified application techniques, improved soil sealing and different combinations of fumigants in the 2008/09 season provided excellent control in some treatments. At Site A, VRR incidence was $0.6 \%$ and $66.7 \%$ in the chloropicrin+metam sodium and chloropicrin treatments, respectively, compared with 98.6\% incidence in untreated control plots. At Site B, VRR incidence was $2.3 \%$ and $3.8 \%$ in the chloropicrin+dichloropropene and combined chloropicrin+dichloropropene+ metam sodium treatments, with and without plastic covering respectively, compared with $41.5 \%$ in untreated control plots.
\end{abstract}

Keywords violet root rot, Rhizoctonia crocorum, carrot, soil sterilisation, fumigation.

\section{INTRODUCTION}

Violet root rot (VRR), caused by the fungal pathogen Rhizoctonia crocorum (teleomorph Helicobasidium purpureum), is a significant disease of carrots in the Ohakune region, New Zealand (Cheah \& Page 1999). It causes substantial economic losses and threatens the long-term viability of the carrot industry in the region. The pathogen has a relatively wide host range, including other crops such as potatoes and parsnips (Punja \& McDonald 2002). Disease symptoms on carrot start as a superficial purplish rot, progressing to rot the carrot completely, leaving only a blackened outer sheath. Fungicides and fumigants have been largely unsuccessful in controlling VRR (Cheah \& Page 1999) and the disease has continued to increase in the Ohakune region.

The aim of the research reported here was to determine whether soil fumigation with commercially available fumigants is capable of controlling VRR in Ohakune carrot fields.

\section{METHODS}

Two sites in the Ohakune region were selected for field trials in 2007/08 (Season 1) and 2008/09 
(Season 2). Both sites were located on Ohakune silt-loam, a free-draining allophanic soil. Site A, between Ohakune and Raetihi, measured 60 $\times 18 \mathrm{~m}$, and Site B at Karioi measured $110 \times 45$ $\mathrm{m}$. Carrots had been grown on both sites in the 2006/07 season, but were not harvested because of very high VRR disease incidence, so there was very high inoculum pressure. Trial areas were thoroughly rotary-hoed before starting the trials, to evenly distribute inoculum in the soil.

The soil fumigation treatments are shown in Table 1. They were applied in mid November 2007 and late November 2008. During fumigation, soil temperatures in the top $20 \mathrm{~cm}$ of soil ranged between 12 and $19^{\circ} \mathrm{C}$. Trials were laid out in randomised block designs, with variable numbers of replicates (Table 1 ). Treated plot sizes were $14 \times$ $1.7 \mathrm{~m}(2007)$ and $17 \times 1.8 \mathrm{~m} \mathrm{(2008)}$ at Site A and $16 \times 5.1 \mathrm{~m} \mathrm{(2007)}$ and $16 \times 6.8 \mathrm{~m} \mathrm{(2008)}$ at Site B. For the metam sodium $\left(\right.$ Fumasol $^{\mathrm{TM}}$ ) treatment, the product was mixed with water to aid even spread, then applied to the soil surface using a watering can and immediately incorporated to a depth of approximately $15 \mathrm{~cm}$ using a rotaryhoe. Immediately following the metam sodium incorporation, dichloropropene+ chloropicrin (as Tri-Form ${ }^{\circledR} 60$, a blend of $40 \%$ Telone ${ }^{\circledR}(1,3-$ dichloropropene) and $60 \%$ chloropicrin) or chloropicrin was shank-injected to a depth of 25$30 \mathrm{~cm}$ in appropriate plots at the rates specified in Table 1 using a commercial tractor-mounted fumigation rig. All plots were then rolled with a heavy tyre-packer to seal the surface. A relatively light ( $\sim 0.6$ tonne) roller was used in 2007. To improve soil sealing, a heavier unit $(\sim 1.5$ tonne $)$ was used in 2008. Clear plastic covers $(30 \mu \mathrm{m}$ polyethylene sheet) were laid on appropriate plots (Table 1), with edges buried to $10 \mathrm{~cm}$ depth, and removed 7 days after fumigation.

In 2007 (Season 1), 24 days after fumigation, plots were rotary hoed ( $\sim 15 \mathrm{~cm}$ deep), to release remaining fumigant gases and prepare the

Table 1 Soil fumigation treatments applied at two Ohakune carrot trial sites in two seasons.

\begin{tabular}{|c|c|c|c|c|}
\hline Year & Site & Treatment & Abbreviation & Reps \\
\hline \multirow[t]{9}{*}{$2007 / 08$} & $\mathrm{~A}$ & 1. Untreated control & Untr & 12 \\
\hline & & 2. Chloropicrin+dichloropropene $\mathrm{e}^{1}\left(50 \mathrm{~g} / \mathrm{m}^{2}\right)$ & ChDi50 & 6 \\
\hline & & 3. Chloropicrin+dichloropropene $\left(30 \mathrm{~g} / \mathrm{m}^{2}\right)$ & ChDi30 & 6 \\
\hline & & 4. Chloropicrin+dichloropropene $\left(30 \mathrm{~g} / \mathrm{m}^{2}\right)+$ plastic & $\mathrm{ChDi} 30+\mathrm{Pl}$ & 6 \\
\hline & & 5. Metam sodium $\left(80 \mathrm{ml} / \mathrm{m}^{2}\right)$ & Ms80 & 6 \\
\hline & $\mathrm{B}$ & 1. Untreated control & Untr & 12 \\
\hline & & 2. Chloropicrin+dichloropropene $\left(50 \mathrm{~g} / \mathrm{m}^{2}\right)$ & ChDi50 & 15 \\
\hline & & 3. Chloropicrin+dichloropropene $\left(30 \mathrm{~g} / \mathrm{m}^{2}\right)$ & ChDi30 & 15 \\
\hline & & 4. Metam sodium $\left(80 \mathrm{ml} / \mathrm{m}^{2}\right)$ & Ms80 & 5 \\
\hline \multirow[t]{6}{*}{ 2008/09 } & $\mathrm{A}$ & 1. Untreated control & Untr & 8 \\
\hline & & 2. Chloropicrin $\left(60 \mathrm{~g} / \mathrm{m}^{2}\right)+$ plastic & $\mathrm{Ch} 60+\mathrm{Pl}$ & 7 \\
\hline & & 3. Chloropicrin $\left(60 \mathrm{~g} / \mathrm{m}^{2}\right)+$ metam sodium $\left(70 \mathrm{ml} / \mathrm{m}^{2}\right)+$ plastic & Ch60+Ms70+Pl & 7 \\
\hline & $\mathrm{B}$ & 1. Untreated control & Untr & 12 \\
\hline & & 2. Chloropicrin+dichloropropene $\left(60 \mathrm{~g} / \mathrm{m}^{2}\right)+$ plastic & $\mathrm{ChDi} 60+\mathrm{Pl}$ & 12 \\
\hline & & 3. Chloropicrin+dichloropropene $\left(60 \mathrm{~g} / \mathrm{m}^{2}\right)+$ metam sodium $\left(70 \mathrm{ml} / \mathrm{m}^{2}\right)$ & ChDi60+Ms70 & 12 \\
\hline
\end{tabular}

${ }^{1}$ Chloropicrin+dichloropropene was a 60/40 w/w blend of chloropicrin and 1,3-dichloropropene. Rates refer to weight of the blended product. 
seedbed. Twenty-eight days after fumigation (mid December), 'Paramount' carrot seed was sown using a commercial seed drill. Beds were the standard $1.7 \mathrm{~m}$ wide at both sites, with plots one bed or three beds wide at Sites A and B, respectively. In 2008 (Season 2), plots were rotary hoed 21 days after fumigation (mid December), and sown with 'Paramount' seed 3 days later. Plots were one (Site A) or two (Site B) beds wide, placed in the centre of the treated strip.

The two field trial sites used in Season 1 were the same as those used in Season 2. By the end of the first season's trials, disease incidence was extremely high and moderately high across Sites $\mathrm{A}$ and $\mathrm{B}$, respectively, regardless of treatment. For the Season 2 trials, the sites were regarded as homogeneous; new plots did not align with previous plots, and the randomisation of treatments disregarded previous treatments. Careful observations made in Season 2 indicated that the homogeneity assumption was not unreasonable.

\section{Assays and assessments}

Gastec $^{\circledR}$ Detector Tubes (Gastec Corporation, Japan) were used to measure concentrations of dichloropropene (Gastec\#132L), chloropicrin (\#134) and metam sodium (\#141L) gases present in the soil at depths of 5 and $25 \mathrm{~cm}$. In Season 1, readings were taken 1, 3, 7 and 14 days following fumigation. In Season 2, readings were taken after $8 \mathrm{~h}, 1,3,7$ and 21 days following fumigation. In both seasons, gas concentrations were measured in three plots per treatment.

Within $1 \mathrm{~h}$ of fumigation, $6 \times 5 \mathrm{~cm}$ nylon mesh bioassay bags were inserted into the soil at depths of 3-5 cm and 15-20 cm in five (Season 1) or six (Season 2) plots of each treatment at both sites. The bags contained approximately 50 ryegrass and 50 clover (Season 1 only) seeds and 20 g orchard soil containing natural populations of Phytophthora cactorum. Bags were retrieved 2 weeks after fumigant application, and seed germination was assessed. The soil containing $P$. cactorum was assayed for oospore survival using an extended apple cotyledon baiting technique (Jeffers \& Aldwinckle 1987).
In both seasons on both sites, significant weed growth was apparent in some plots 3 weeks after fumigation. Weed plant numbers were counted in $40 \times 40 \mathrm{~cm}$ quadrats randomly placed within each plot, with three quadrats per plot in Season 1 and eight quadrats per plot in Season 2. Weed count data were analysed using ANOVA (Minitab $15^{\mathrm{TM}}$ ).

Assessments of carrot plant health were made at both sites in mid March and July 2008 (Season 1 ), and in late March, early May and early July 2009 (Season 2). At the various sampling times, between 16 and 60 plants were assessed in each plot by lifting plants at uniform intervals, brushing carefully to remove soil, and scoring VRR disease symptoms on the roots. Disease severity ratings were: 'healthy' $=$ no symptoms, 'trace' $=$ minor/ superficial infection, 'moderate' $=$ up to $50 \%$ of the carrot infected, 'major' $=50-75 \%$ of carrot infected, 'severe' $=$ more than $75 \%$ of the carrot infected. To minimise plot edge effects, only plants in the central $8 \mathrm{~m}$ of plots were assessed. Disease incidence data (proportion of healthy plants) were analysed in SAS 9.1 using the Logistic Procedure that allowed for over-dispersion. For this analysis, plants showing any symptom of VRR were merged into one 'diseased' category.

Soon after carrot seed emergence in Season 2, suppressed growth was noted in some plots. In early February 2009, transects were laid across plots, and 8 to 10 carrots per plot were harvested, oven-dried and weighed. Carrot weight data were analysed using ANOVA (Minitab $15^{\mathrm{TM}}$ ).

\section{RESULTS}

\section{Gas readings}

A summary of gas readings from Site B is given in Figure 1. In Season 1, initial (within 1 day) concentrations of dichloropropene and chloropicrin were low near the soil surface (5 $\mathrm{cm}$ depth), but higher concentrations were detected near the depth of application $(25 \mathrm{~cm})$. Chloropicrin had mostly dispersed from the soil within 7 days, but low concentrations of dichloropropene were still detected after 14 days. In Season 2, however, the initial concentrations of dichloropropene and chloropicrin detected in soil were much higher, both at 5 and $25 \mathrm{~cm}$ depths. 
Chloropicrin had mostly dispersed within 7 days, but moderate concentrations of dichloropropene were still detectable after 21 days.

Metam sodium concentrations were also higher in Season 2 than in Season 1, despite a lower application rate the second year. Although concentrations were relatively high at $5 \mathrm{~cm}$ depth, they were low at $25 \mathrm{~cm}$ depth, reflecting the relatively poor movement in soil following surface application and incorporation of this product by hoeing to $15 \mathrm{~cm}$. Patterns of gas concentration and dispersion in soil at Site A were similar to those at Site B (data not presented). Covering soil with plastic immediately following fumigation had minimal impact on the concentrations of gas measured in soil (data not presented), although related studies had indicated that plastic covers prolonged the time taken for total release of gases from the soil (I.J. Horner, unpublished data).

\section{Buried seed and inoculum}

Assays of fungal inoculum and seed survival in buried bags retrieved 2 weeks after fumigation are summarised in Table 2. In Season 1, all samples retrieved from untreated control plots had high germination rates of ryegrass seed and a high rate of Phytophthora survival. None of the chloropicrin+dichloropropene treatments killed ryegrass seed and Phytophthora oospores at both the 5 and $15 \mathrm{~cm}$ depths. At Site A, chloropicrin+dichloropropene at $50 \mathrm{~g} / \mathrm{m}^{2}$ killed most seed and some of the Phytophthora at $15 \mathrm{~cm}$ depth, but was less effective nearer the surface. The lower rate of chloropicrin+dichloropropene $\left(30 \mathrm{~g} / \mathrm{m}^{2}\right)$ reduced seed germination at $15 \mathrm{~cm}$ depth but had no effect on germination at $5 \mathrm{~cm}$ or Phytophthora survival at either depth. Both treatments were less effective at Site B. Covering the low rate of chloropicrin+dichloropropene with plastic immediately after fumigation at Site A, improved seed kill and eradicated Phytophthora from bags at $5 \mathrm{~cm}$ depth, but had no measurable effect at $15 \mathrm{~cm}$ depth. Soil temperatures in the top $5 \mathrm{~cm}$ of soil under plastic covers (measured on one occasion 7 days after fumigation) were $41^{\circ} \mathrm{C}$, and these may have contributed to the seed and fungus mortality near the surface. Temperatures at $15 \mathrm{~cm}$ did not exceed $30^{\circ} \mathrm{C}$. The metam sodium treatment substantially reduced seed germination and Phytophthora survival at both 5 and $15 \mathrm{~cm}$, but some seeds and spores survived in just one of the ten replicate bags buried at each depth.

In Season 2, seed germination and Phytophthora spore viability were high in all bags retrieved from untreated control sites. There was no survival of Phytophthora and minimal germination of seeds in both of the treatment combinations that included metam sodium, or where the chloropicrin+dichloropropene was sealed with plastic. Where chloropicrin was the
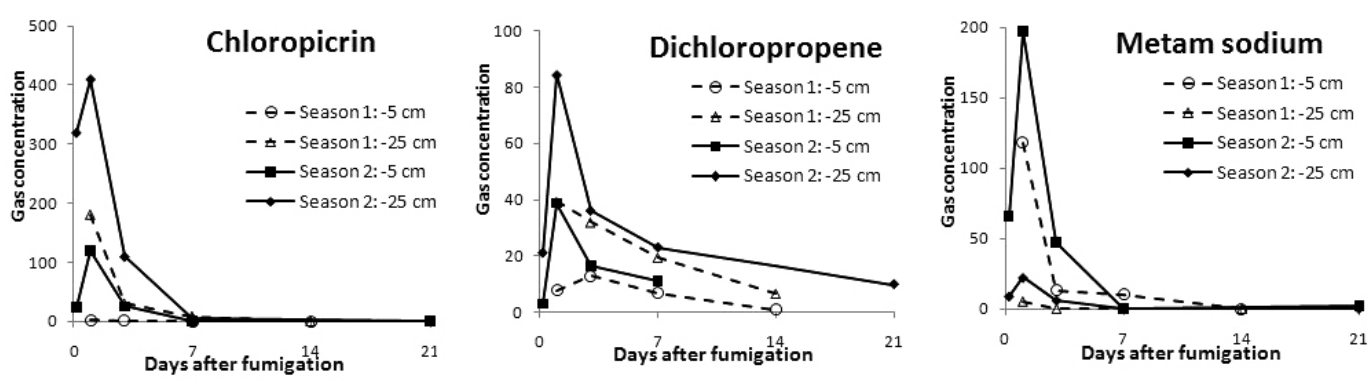

Figure 1 Mean soil concentrations (ppm) of three fumigant gases measured in Ohakune soil (Site B) at $5 \mathrm{~cm}$ and $25 \mathrm{~cm}$ depths at various times following fumigant application. For Season 1, measurements of dichloropropene and chloropicrin are from the chloropicrin+dichloropropene $\left(50 \mathrm{~g} / \mathrm{m}^{2}\right)$ treatment, and metam sodium measurements are from the metam sodium $\left(80 \mathrm{ml} / \mathrm{m}^{2}\right)$ treatment. For Season 2, all measurements were from the combined chloropicrin+dichloropropene (60 g/m²) + Fumasol (70 ml/ $\mathrm{m}^{2}$ ) treatment. 
Table 2 Phytophthora cactorum survival and ryegrass (RG) or clover seed germination (\%) from sample bags buried immediately after fumigation, and retrieved 2 weeks later. Data are from two seasons at two Ohakune sites. Full treatment descriptions are given in Table 1

\begin{tabular}{|c|c|c|c|c|c|c|c|}
\hline \multirow[b]{3}{*}{ Treatment } & \multirow[b]{3}{*}{ Depth } & \multicolumn{4}{|c|}{ Seed viability (\% germination) } & \multicolumn{2}{|c|}{ Phytophthora survival ${ }^{1}$} \\
\hline & & \multicolumn{2}{|c|}{ Site A } & \multicolumn{2}{|c|}{ Site B } & \multirow{2}{*}{ Site A } & \multirow{2}{*}{ Site B } \\
\hline & & RG & Clover & RG & Clover & & \\
\hline \multicolumn{8}{|l|}{ Season 1} \\
\hline \multirow{2}{*}{ Untr } & $5 \mathrm{~cm}$ & 100 & $\mathrm{ND}^{2}$ & 100 & ND & 5 & 5 \\
\hline & $15 \mathrm{~cm}$ & 100 & ND & 93 & ND & 5 & 5 \\
\hline \multirow{2}{*}{ ChDi50 } & $5 \mathrm{~cm}$ & 65 & ND & 85 & ND & 5 & 5 \\
\hline & $15 \mathrm{~cm}$ & 0 & ND & 28 & ND & 3 & 5 \\
\hline \multirow{2}{*}{ ChDi30 } & $5 \mathrm{~cm}$ & 100 & ND & 96 & $\mathrm{ND}$ & 5 & 5 \\
\hline & $15 \mathrm{~cm}$ & 33 & ND & 70 & ND & 5 & 5 \\
\hline \multirow{2}{*}{$\mathrm{ChDi30+Pl}$} & $5 \mathrm{~cm}$ & 33 & ND & $--^{2}$ & $\mathrm{ND}$ & 0 & - \\
\hline & $15 \mathrm{~cm}$ & 37.5 & ND & - & ND & 5 & - \\
\hline \multirow{2}{*}{ Ms 80} & $5 \mathrm{~cm}$ & 0 & ND & 20 & $\mathrm{ND}$ & 0 & 1 \\
\hline & $15 \mathrm{~cm}$ & 0 & ND & 12 & $\mathrm{ND}$ & 0 & 1 \\
\hline \multicolumn{8}{|l|}{ Season 2} \\
\hline \multirow{2}{*}{ Untr } & $5 \mathrm{~cm}$ & 98 & 89 & 98 & 88 & 6 & 6 \\
\hline & $20 \mathrm{~cm}$ & 99 & 90 & 98 & 90 & 5 & 5 \\
\hline \multirow{2}{*}{ Ch60+Pl } & $5 \mathrm{~cm}$ & 45 & 25 & - & - & 1 & - \\
\hline & $20 \mathrm{~cm}$ & $6^{3}$ & $7^{3}$ & - & - & 1 & - \\
\hline \multirow{2}{*}{$\mathrm{Ch} 60+\mathrm{Ms} 70+\mathrm{Pl}$} & $5 \mathrm{~cm}$ & 0 & 0 & - & - & 0 & - \\
\hline & $20 \mathrm{~cm}$ & $1^{3}$ & 0 & - & - & 0 & - \\
\hline \multirow{2}{*}{ ChDi60+Pl } & $5 \mathrm{~cm}$ & - & - & 0 & 0 & - & 0 \\
\hline & $20 \mathrm{~cm}$ & - & - & 0 & 0 & - & 0 \\
\hline \multirow{2}{*}{ ChDi60+Ms70 } & $5 \mathrm{~cm}$ & - & - & $1^{3}$ & 0 & - & 0 \\
\hline & $20 \mathrm{~cm}$ & - & - & 0 & 0 & - & 0 \\
\hline
\end{tabular}

${ }^{1}$ Phytophthora survival is recorded as the number of bags out of five (Season 1) or six (Season 2) sampled where live Phytophthora cactorum could be detected using a baiting assay.

${ }^{2} \mathrm{ND}=$ not determined; $-=$ treatment not set up at that site.

${ }^{3}$ Just one bag of the six sampled had any viable seeds.

sole fumigant used, survival of seeds was high relative to that of other fumigation treatments, particularly near the soil surface. There was also a low level of Phytophthora survival in the chloropicrin-only treatment.

\section{Weed plant numbers}

In both seasons, substantial numbers of weeds were evident in some plots 3 weeks after fumigation (Table 3). In Season 1, the low rate of chloropicrin+dichloropropene $\left(30 \mathrm{~g} / \mathrm{m}^{2}\right)+$ plastic cover and metam sodium treatments were most effective at reducing natural weed seed establishment, with a highly significant $(\mathrm{P}<0.001)$ reduction compared with the untreated control. However, the low rate of chloropicrin+dichloropropene without a plastic cover had minimal impact on weed germination. The high rate of chloropicrin+dichloropropene $\left(50 \mathrm{~g} / \mathrm{m}^{2}\right)$, without plastic roughly halved the number of weed seedlings, compared with the untreated control.

In Season 2 on both sites, there was significantly $(\mathrm{P}<0.01)$ higher establishment of weeds in untreated control plots than any fumigated treatments (Table 3). Plots treated with either 
Table 3 Mean number of weeds $/ \mathrm{m}^{2}$ in plots 3 weeks after treatment with various fumigants at two Ohakune sites in two seasons.

\begin{tabular}{llcl}
\hline Season & Treatment & Site A & Site B \\
\hline 1 & Untreated control & 40.0 & 81.9 \\
& Chloropicrin+dichloropropene $\left(50 \mathrm{~g} / \mathrm{m}^{2}\right)$ & $18.4^{* 1}$ & $44.2^{\star}$ \\
& Chloropicrin+dichloropropene $\left(30 \mathrm{~g} / \mathrm{m}^{2}\right)$ & 36.8 & 52.1 \\
& Chloropicrin+dichloropropene $\left(30 \mathrm{~g} / \mathrm{m}^{2}\right)+$ plastic & $1.7^{\star}$ & $-^{2}$ \\
& Metam sodium $\left(80 \mathrm{ml} / \mathrm{m}^{2}\right)$ & $0.7^{\star}$ & $11.7^{\star}$ \\
& & & \\
& & 151.0 & 76.0 \\
& Untreated control & $54.0^{\star}$ & - \\
Chloropicrin $\left(60 \mathrm{~g} / \mathrm{m}^{2}\right)+$ plastic & $0.4^{*}$ & - \\
Chloropicrin $\left(60 \mathrm{~g} / \mathrm{m}^{2}\right)+$ metam sodium $\left(70 \mathrm{ml} / \mathrm{m}^{2}\right)+$ plastic & - & $6.7^{\star}$ \\
Chloropicrin+dichloropropene $\left(60 \mathrm{~g} / \mathrm{m}^{2}\right)+$ plastic & - & $9.6^{\star}$ \\
Chloropicrin+dichloropropene $\left(60 \mathrm{~g} / \mathrm{m}^{2}\right)+$ metam sodium $\left(70 \mathrm{ml} / \mathrm{m}^{2}\right)$ & -
\end{tabular}

${ }^{1 *}=$ mean is significantly different $(\mathrm{P}<0.05)$ from the untreated control at the same site in the same season.

${ }^{2}-=$ treatment not set up at that site.

metam sodium or chloropicrin+dichloropropene had minimal weed growth at both sites. The chloropicrin+plastic cover treatment on Site A had relatively high numbers of weeds compared with a similar treatment that included metam sodium, but still had fewer weeds than the untreated control. This pattern was continued throughout the season, with ongoing weed growth in the untreated control and 'chloropicrin only' treatments, and minimal weed growth in chloropicrin+dichloropropene or metam sodium-treated plots.

\section{Disease assessments}

In Season 1 the first above-ground disease symptoms appeared in mid to late March 2008, and by early May 2008 large areas were showing severe above-ground disease symptoms. By July 2008, most of the trial area exhibited severe disease symptoms, regardless of treatment. At the time of assessment in March 2008, there were few obvious above-ground symptoms of disease, yet below ground there was already a high incidence of VRR infection, with $80 \%$ and $22 \%$ of carrots in untreated control plots infected at Sites A and B, respectively. The metam sodium treatment had, on average, the lowest incidence and severity of infection, although differences were not statistically significant compared with the untreated control. There was wide variability in disease levels between plots, possibly because of patchy distribution of the disease in the fields. By July 2008, the incidence of VRR in untreated control plots had increased to $90 \%$ at Site A and to $49 \%$ at Site B. Although disease incidence was slightly lower in fumigated than in untreated plots, none of the differences between treatments was statistically significant $(\mathrm{P}>0.05)$.

In Season 2, the various fumigant combinations used were much more effective at controlling VRR than those used in the previous season. On both trial sites, there was a highly significant difference $(\mathrm{P}<0.0001)$ in the incidence of VRR disease between the various fumigant treatments and the untreated control (Figure $2)$. In the untreated control plots, there was a high incidence of VRR by the time of the first assessment 3 months after planting (late March 2009), with 90 and 24\% VRR incidence on Sites A and B, respectively (Figure 2). Disease incidence increased during the season to 99 and $41 \%$ by early July 2009 at Sites A and B, respectively. There was a concomitant increase in severity of symptoms on the carrots in the untreated control 
Table 4 Mean dry weight (g) of randomly selected carrot plants harvested from two Ohakune trial sites approximately 5 weeks after sowing, following treatment with various fumigants in late November 2008 (Season 2).

\begin{tabular}{lcc}
\hline Treatment & Site A & Site B \\
\hline Chloropicrin $\left(60 \mathrm{~g} / \mathrm{m}^{2}\right)+$ plastic & 0.122 & - \\
Chloropicrin $\left(60 \mathrm{~g} / \mathrm{m}^{2}\right)+$ metam sodium $\left(70 \mathrm{ml} / \mathrm{m}^{2}\right)+$ plastic & $0.020^{\star 1}$ & - \\
Chloropicrin+dichloropropene $\left(60 \mathrm{~g} / \mathrm{m}^{2}\right)+$ metam sodium $\left(70 \mathrm{ml} / \mathrm{m}^{2}\right)$ & - & $0.081^{\star}$ \\
Chloropicrin+dichloropropene $\left(60 \mathrm{~g} / \mathrm{m}^{2}\right)+$ plastic & - & 0.158 \\
Untreated control & 0.127 & 0.151 \\
\hline
\end{tabular}

${ }^{1 *}=$ mean is significantly different $(\mathrm{P}<0.05)$ from the untreated control at the same site.

plots, with almost all carrots in the 'severe' category on the Site A by July 2009. In contrast to untreated controls, disease incidence was substantially lower in fumigated plots; $P$ values for Site A were: chloropicrin+plastic $(\mathrm{P}=0.0118)$ and chloropicrin +metamsodium + plastic $(\mathrm{P}<0.0001)$; and for Site B: chloropicrin+dichloropropene + plastic and chloropicrin+dichloropropene+ metam sodium $(\mathrm{P}<0.0001)$. At Site $\mathrm{B}$, in the chloropicrin+dichloropropene-treated plots
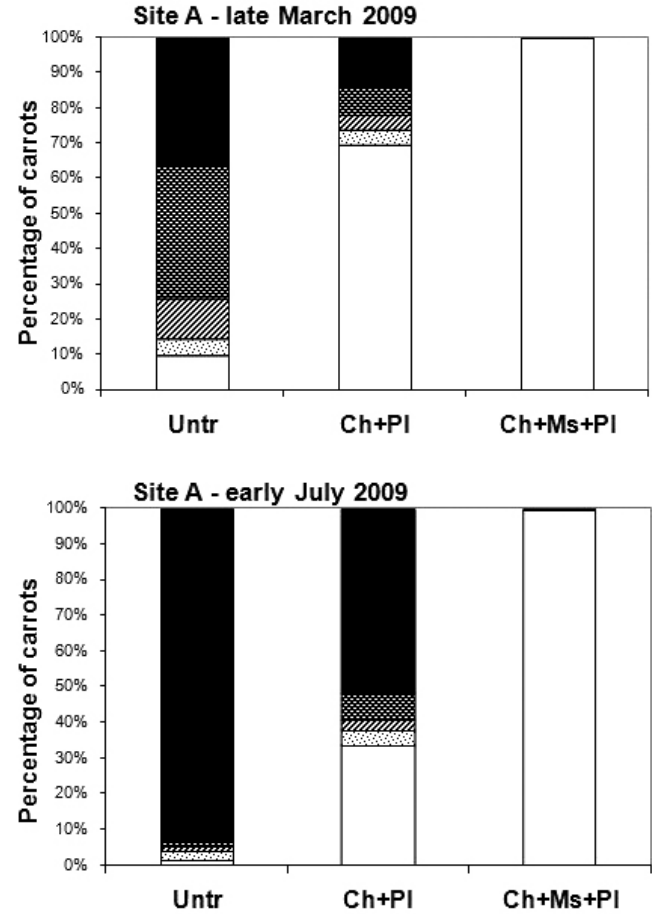

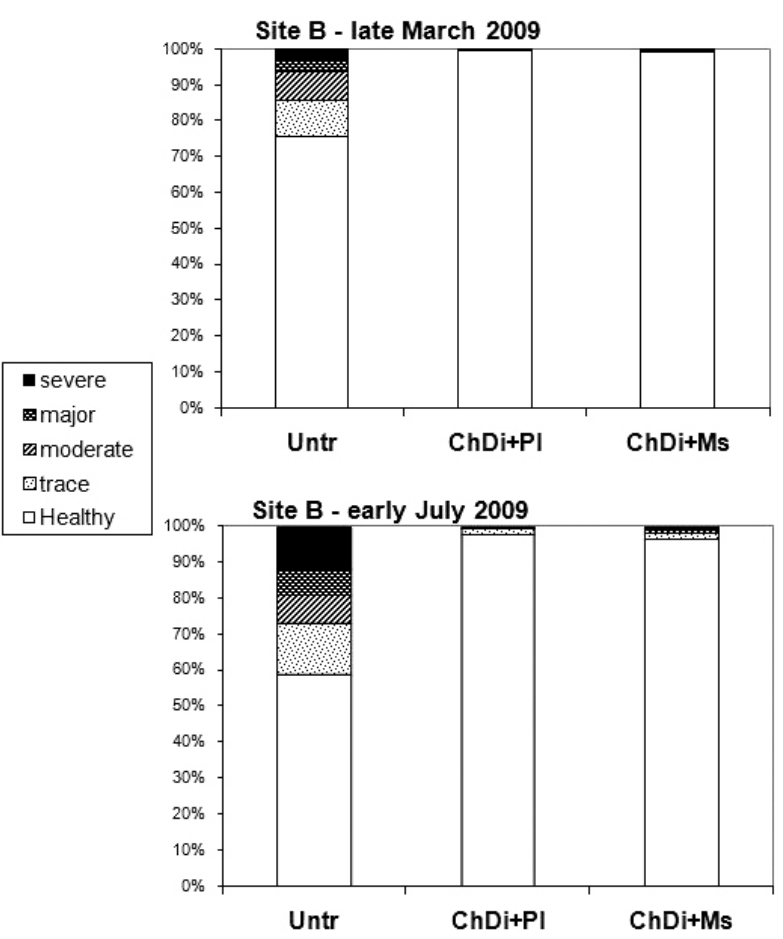

Figure 2 Average incidence of carrots with violet root rot symptoms of varying severity grown in two Ohakune trial sites following treatment with various fumigant combinations in November 2008 (Season 2). Data are based on inspection of 1880 and 1968 carrot roots in late March and early July 2009 assessments, respectively. $\mathrm{Ch}=$ chloropicrin $\left(60 \mathrm{~g} / \mathrm{m}^{2}\right), \mathrm{ChDi}=$ chloropicrin+dichloropropene $\left(60 \mathrm{~g} / \mathrm{m}^{2}\right), \mathrm{Ms}=$ metam sodium $\left(70 \mathrm{ml} / \mathrm{m}^{2}\right), \mathrm{Pl}=$ plastic cover. 
with either a plastic cover or combined with metam sodium, carrots had relatively low disease incidence throughout the season, with less than $4 \%$ of carrots infected with VRR. At Site A, the chloropicrin+metam sodium+plastic treatment resulted in less than $1 \%$ infection, compared with 99\% infection in adjacent untreated plots. The chloropicrin treatment without metam sodium provided only partial disease control, with $31 \%$ incidence in March 2009, increasing to $67 \%$ by July 2009.

\section{Phytotoxicity}

In Season 1, when carrot seed was sown 4 weeks after fumigation, there was no evidence of delayed germination or phytotoxicity caused by residual fumigants in any of the plots. However, in Season 2, early season carrot plant growth was substantially reduced by fumigant treatments, particularly those containing metam sodium (Table 4), compared with untreated control plots. Although plant growth was substantially delayed, it appeared to have recovered by the end of the season. However, late-season comparisons of plant growth could not be made, as most plants in untreated control plots were severely rotted by VRR.

\section{DISCUSSION}

In the first season of field fumigation trials, none of the fumigant treatments was effective at controlling VRR. Examination of results for pathogen and seed kill, gas movement in the soil, and subsequent VRR control revealed probable reasons for the failure. The assessments of fumigant concentration in the soil showed that the chloropicrin+dichloropropene mixture failed to reach high concentrations at the soil surface, even when applied under plastic covers. These chemicals were shank injected to $25 \mathrm{~cm}$ depth, and concentrations at this depth were high. But as the chemicals dispersed throughout the soil profile, they were lost from the soil surface without reaching sufficient concentration to kill pathogen inoculum. This was reflected in the buried seed and Phytophthora inoculum assays, with good seed kill and partial Phytophthora kill at $15 \mathrm{~cm}$ depth, but minimal effect at $5 \mathrm{~cm}$. In contrast to the chloropicrin+dichloropropene distribution in soil, metam sodium was only distributed at high concentration near the soil surface. Gas concentrations measured at $25 \mathrm{~cm}$ depth were low, indicating poor dispersal beyond the area of incorporation into the soil (the top $15 \mathrm{~cm}$ ). Thus, it seems likely that the failure of the chloropicrin+dichloropropene treatments related to survival of VRR inoculum in the surface layers of soil where gas concentrations remained low, and the failure of metam sodium resulted from inoculum survival at depths beyond the incorporation zone.

By the end of Season 1, disease incidence was extremely high and moderately high across Sites $\mathrm{A}$ and $\mathrm{B}$, respectively, regardless of treatment. In the second season, the same sites were used and they were regarded as being homogeneous; new plots did not align with previous plots, and the randomisation of treatments disregarded previous treatments.

Treatments selected in Season 2 attempted to address the gas distribution problems by combining shank-injected chloropicrin+ dichloropropene or chloropicrin treatments with surface-applied metam sodium treatments. Slightly higher rates of chloropicrin + dichloropropene were also used, as there was a suggestion of a rate effect in the seed and pathogen kill studies in the previous season. In addition, a heavier roller was used to seal the surface following fumigant application, as the Season 1 study showed that soil sealing was not adequate to retain gases at high concentration near the surface.

In contrast to treatments in Season 1, a number of the fumigation treatments trialled in the second season provided outstanding control of violet root rot. Disease incidence in untreated control plots was very high in both trial sites, indicating high disease pressure, yet carrots grown in some of the fumigant treatments had almost no VRR symptoms. On Site B, treatment with chloropicrin+dichloropropene at $60 \mathrm{~g} / \mathrm{m}^{2}$ + plastic was very effective at controlling VRR, with $2 \%$ disease compared with $42 \%$ disease in untreated control plots. A similar treatment the 
previous season, but at a lower application rate (30 $\mathrm{g} / \mathrm{m}^{2}$ ) and using a light roller, was not effective. It is likely that the dichloropropene component in this mix provided part of the observed control of both seeds and fungal inoculum because chloropicrin alone, even with a plastic cover, failed to provide adequate control of VRR at Site A, and also failed to control natural weed growth adequately. The results from buried seed and pathogen assays also indicated that chloropicrin alone did not kill all pathogens and seeds, particularly near the soil surface. Measurements of gas levels in soil showed that chloropicrin concentrations near the soil surface were much lower than deeper in the profile, perhaps explaining the relatively poor disease and weed control with this treatment.

In Season 2 treatments combining metam sodium with chloropicrin+dichloropropene or chloropicrin provided a significant degree of disease and weed control. At both sites, treatments including metam sodium gave season-long control of VRR and killed seed and pathogen inoculum in the soil. Even without a plastic cover treatment, combining metam sodium and chloropicrin+dichloropropene was effective, with only $3 \%$ VRR incidence at Site B, compared with $42 \%$ in the untreated control. This treatment has potential for use in the Ohakune region, where high winds and rainfall, plus the environmental and financial cost of plastic, may preclude use of broad-acre plastic covers during fumigation.

In general, results of buried seed and Phytophthora inoculum survival correlated well with VRR incidence data in the planted carrot crop, demonstrating the usefulness of these assays as indicators of fumigant activity and biocidal effectiveness in the soil. The Phytophthora assay was non-quantitative so cannot be used to conclude that some treatments had no effect on fungal survival. A single surviving spore in a sample bag could potentially give a positive sample result. However, Phytophthora survival generally correlated with seed survival, which was quantitative. Similar work with this technique in other crops and soils has consistently given total kill of Phytophthora spores with some of the same fumigants used in the current trials (Horner
1999). Ideally, Rhizoctonia crocorum inoculum would have been used in the carrot trial bag assays, but this fungus is particularly difficult to retrieve into culture and assay for viability, thus the Phytophthora and weed assays were chosen as a quick and easy indicator.

The early-season stunting of carrot growth observed in some treatments during the Season 2 trial was probably a result of phytotoxicity. The treatments that included metam sodium had particularly slow plant growth early in the season, although soil monitoring at planting did not reveal high metam sodium residues. However, the metam sodium probably degraded to a number of potentially toxic breakdown products (Ruzo 2006) that were still present at planting time and not detected by the specific gas probes that were used. Dichloropropene residues were still detected at the time of planting in some plots, in concentrations shown to cause phytotoxicity in trials with other crops (Mattner et al.2003). This apparent phytotoxicity observed in Season 2 can be attributed to three factors. Firstly, high fumigant rates were used in this trial, in part, to determine whether the fumigants were capable of controlling the disease. Secondly, carrot seed was sown just over 3 weeks from fumigation, probably at least a week too soon. Thirdly, aeration was inadequate as soil was cultivated just once, to a relatively shallow depth, between fumigation and sowing. However, more frequent cultivation and deeper working of the soil using a tractor-mounted hoe (the preferred practice) was not possible because of the trial layout and the need to maintain plot integrity and avoid cross-contamination. The improved soil sealing and gas retention in the second year, which probably improved VRR control, probably also contributed to the phytotoxicity problem. Thus, it is recommended that the waiting period post-fumigation before planting carrot seed is increased and if possible, soil aeration improved by repeated cultivation between fumigation and planting.

There was no evidence from the gas readings that the plastic cover helped in gas retention. Most fumigant gases are known to move 
rapidly through standard polyethylene barriers (Papiernik et al. 2001). However, when the plastic was lifted 7 days after fumigation, there was a noticeable smell of residual gas, indicating that the film had contained at least a proportion of the fumigant. The inclusion of the polyethylene plastic cover in the trial gave no improvement in violet root rot control. The increased mortality of seeds and fungal propagules in the surface layers of soil under plastic probably resulted from increased soil temperatures.

The improved VRR control during Season 2 is likely to result from higher chemical rates, use of a heavier roller improving soil sealing and gas retention, and in some cases, by combining chloropicrin+dichloropropene shank-injection with surface incorporation of metam sodium to ensure fumigant gas distribution throughout the soil profile. The chemical rates used in Season 2 are at the upper end of label rates. Further trials are in progress to determine whether lower rates or different fumigant combinations will still provide effective control of VRR. This information will be assimilated to provide a more economically viable option for growers, and reduce potential phytotoxicity and waiting periods required before planting.

\section{ACKNOWLEDGEMENTS}

This work was funded by the Fresh Vegetable Product Group and Potato Groups of Horticulture New Zealand, and by the Ministry of Agriculture and Forestry's Sustainable Farming Fund. Terranova Ltd, Ballance AgriNutrients Ltd, Dow Agrosciences and Elliott Technologies all supplied trial products and Leicesters Fumigation Ltd provided fumigation services. Thanks also to Ohakune growers and Kath Lee-Jones for provision of land and assistance with trials.

\section{REFERENCES}

Cheah LH, Page BBC 1999. Epidemiology and control of violet root rot of carrots. Proceedings of the 52nd New Zealand Plant Protection Conference: 157-161.

Horner IJ 1999. Alternative soil fumigant trials in New Zealand strawberry production. Proceedings of the Annual International Research Conference on Methyl Bromide Alternatives and Emissions Reductions, San Diego, USA, November 1999. Pp. 87/1 to $87 / 4$.

Jeffers SN, Aldwinckle HS 1987. Enhancing detection of Phytophthora cactorum in naturally infested soil. Phytopathology 77: 1475-1482.

Mattner SW, Porter IJ, Gounder RK, Shanks AL 2003. Phytotoxicity and plantback- critical issues in the Australian strawberry industry. Proceedings of the Annual International Research Conference on Methyl Bromide Alternatives and Emissions Reductions, San Diego, USA, November 2003. Pp. 41/1 to $41 / 4$

Papiernik SK, Yates SR, Gan J 2001. An approach for estimating the permeability of agricultural films. Environmental Science \& Technology 35: $1240-1246$.

Punja ZK, McDonald MR 2002. Violet Root Rot. In: Davis RM, Raid RN ed. Compendium of Umbelliferous Crop Diseases. APS Press, St Paul, Minnesota, USA. Pp. 40-41.

Ruzo LO 2006. Physical, chemical and environmental properties of selected chemical alternatives for the pre-plant use of methyl bromide as soil fumigant. Pest Management Science 62: 99-113. 